\title{
PENGEMBANGAN PAKET PERKULIAHAN READING BERKELANJUTAN JURUSAN PENDIDIKAN BAHASA INGGRIS UNDIKSHA
}

\author{
Luh Putu Artini \\ Jurusan Pendidikan Bahasa Inggris \\ Fakultas Bahasa dan Seni, Universitas Pendidikan Ganesha \\ Jalan Jend. A. Yani 67 Singaraja 81116, Telp. 0362-21541, Fax. 0362-27561 \\ E-mail: putu.artini@undiksha.ac.id
}

\begin{abstract}
This research aims at developing the syllabus and instructional materials for Reading course series in English Education Department, Ganesha University of Education. This Reading course comprises four series: Reading I (Literal Reading), Reading II (Intepretive Reading), Reading III (Critical Reading) and, Advanced Reading (Reading from the Media). The research was inspired by preliminary findings about unclear transition and focus of each serial of reading course. These include the degree of complexity and coverage of the texts, instructional strategies and teaching strategies. As a matter of fact, reading is a stepping stone for developing other language skills such as writing, speaking and listening (Guthrie\& Kirsch, 2007). The first year of the research has resulted in the adapted syllabus and blueprint for the material development. In the second year the instructional materials for levelled reading courses were developed and validated and was checked its relevance and readability. Data analysis found that the product was highly relevant to the syllabus and provide with Engliah language teaching. This indicates that the quality of the product can be categorized as very good and as systematic gradation, focus, depth and scope.
\end{abstract}

Key words: lecture package, levelled reading, adult learners

\begin{abstract}
ABSTRAK
Penelitian ini bertujuan untuk mengembangkan silabus dan materi perkuliahan untuk mata kuliah Reading berseri di Jurusan Pendidikan Bahasa Inggris, Universitas Pendidikan Ganesha. Perkuliahan Reading terdiri dari 4 seri yaitu Reading I (Literal Reading), Reading II (Interpretive Reading), Reading III (Critical Reading) dan Advanced Reading (Reading from the Media). Penelitian ini diinspirasi oleh adanya ketidakjelasan target pencapaian dari masing-masing jenjang perkuliahan dan belum adanya transisi yang terencana pada tingkat kesulitan teks, kedalaman materi, strategi pembelajaran maupun jenis dan strategi asesmen yang digunakan. Sesungguhnya kuliah Reading merupakan dasar pengembangan ketrampilan berbahasa Inggris karena dari kegiatan membaca bisa dikembangkan ketrampilan menulis, berbicara dan mendengarkan (Guthrie\& Kirsch, 2007). Pada tahun pertama penelitian telah menghasilkan adaptasi silabus dan kisi-kisi pengembangan materi dan selanjutnya pada tahun kedua materi perkuliahan Reading berkelanjutan dikembangkan dan diuji relevansi dan tingkat keterbacaan teks dari keempat jenjang materi. Hasil analisis terhadap produk penelitian ini menunjukkan bahwa produk pengembangan memiliki relevansi yang tinggi terhadap silabus dan memberi kesempatan bagi mahasiswa untuk mengembangkan kemampuan baca dan tulis mahasiswa di Jurusan Pendidikan Bahasa Inggris. Dari hasil validasi konten, kualitas produk ada dalam kategori sangat baik dan memiliki gradasi, fokus, kedalaman dan keluasan materi yang sistematis.
\end{abstract}

Kata Kunci: paket perkuliahan, reading berkelanjutan, pebelajar dewasa 


\section{PENDAHULUAN}

Di Jurusan Pendidikan Bahasa Inggris Undiksha, kurikulum ditata sedemikian rupa sehingga lulusan memiliki kompetensi profesional dan pedagogis yang kuat. Untuk kompetensi profesional yang kuat, mahasiswa dibekali dengan profisiensi Bahasa Inggris yang tinggi melalui mata kuliah ketrampilan berbahasa Inggris berseri dari semester awal sampai semester lima. Mata kuliah ketrampilan berbahasa tersebut terdiri dari Speaking, Listening, Reading dan Writing.

Sampai saat ini beberapa upaya sudah dilakukan untuk meningkatkan kualitas perkuliahan mata kuliah ketrampilan berbahasa, misalnya, pengembangan materi Speaking I (Ratminingsih, dkk., 2013); pengembangan materi Writing berbasis IT (Surya Adnyani, dkk., 2013). Tetapi berdasarkan pengamatan peneliti, untuk Mata Kuliah Reading yang terdiri dari 4 serial, masih terdeteksi beberapa masalah, yaitu: pertama, dosen pengampu mata kuliah Reading mengembangkan silabus dan Satuan Acara Perkuliahan (SAP) sendiri tanpa koordinasi dengan pengajar Reading yang lain sehingga kesinambungan atau keberlanjutan dan fokus/materi perkuliahan belum direncanakan dengan baik.

Masalah kedua terkait dengan adanya kebiasaan menentukan sendiri materi yang digunakan dengan strategi pembelajaran yang disesuaikan dengan teaching style masingmasing. Otonomi dalam hal membuat silabus, menentukan materi dan strategi pembelajaran sendiri berakibat lemahnya standar pembelajaran. Jurusan pendidikan Bahasa Inggris memiliki 4 sampai 9 kelas paralel untuk masing-masing angkatan sehingga memerlukan 4-9 dosen yang mengajar mata kuliah yang sama. Otonomi dosen dalam menyelenggarakan perkuliahan berdampak terhadap ketidakseragaman model yang diimplementasikan pada mata kuliah yang sama di kelas yang berbeda yang selanjutnya berdampak pada ketidakjelasan target pencapaian perkuliahan.

Sebagai sebuah Lembaga Pendidikan Tenaga Kependidikan, Undiksha memiliki tanggung jawab untuk mencetak calon-calon guru profesional, termasuk di dalamnya adalah calon guru Bahasa Inggris. Sebagaimana diketahui, kebutuhan untuk bisa berbahasa Inggris semakin dirasakan oleh segenap lapisan masyarakat sekarang ini. Salah satu alasan popularitas Bahasa Inggris adalah karena dimulainya Masyarakat Ekonomi Asia (MEA) pada akhir tahun 2015. Mata kuliah Reading juga merupakan penanaman karakter gemar membaca, belajar mandiri, dan mengasah ketrampilan berpikir logis, objektif, kritis dan kreatif (Killen, 2002). Untuk memiliki lulusan sekolah menengah atas sekolah menengah kejuruan yang siap pakai dan memiliki daya saing tinggi, pembelajaran Bahasa Inggris harus memiliki proses dan produk yang sangat baik. Kunci dari semua ini adalah guru Bahasa Inggris juga harus berkualitas dan muara dari semua ini adalah LPTK yang berkualitas.

Membaca dalam bahasa asing memerlukan suatu strategi yang lebih dari pada membaca dalam bahasa pertama. Kompleksitas membaca dalam bahasa asing disebabkan oleh karena pemahaman terhadap bacaan dipengaruhi oleh penguasaan bahasa dan pemahaman konteks bacaan sebagaimana yang disampaikan oleh Wixon dkk. (1987) sebagai berikut.

"...reading is the process of constructing meaning through the dynamic interaction among the reader's existing knowledge; the information suggested by the text being read; and the context of the reading situation"

Pada kutipan di atas tersurat adanya tiga faktor yang saling berinteraksi untuk terjadinya sebuah pemahaman yang baik ketika membaca dalam bahasa asing. Faktor tersebut adalah latar belakang pengetahuan pembaca tentang topik yang dibacanya, informasi yang tersurat dan tersirat dalam bacaan, dan konteks situasi membaca.

Lebih jauh, Whorter (2005) mengklasifikasikan 4 faktor yang menentukan kemampuan memahami bacaan dalam bahasa asing yaitu: 1) latar belakang pengetahuan, 2) kondisi fisik dan mental, 3) tingkat ketertarikan pembaca terhadap topik bacaan, dan 4) ketrampilan membaca awal. Latar belakang 
pengetahuan memang memiliki peran yang sangat penting dan oleh sebab itu selalu menjadi faktor pertama yang diungkap pada setiap literatur tentang pemahaman dalam membaca, baik dalam bahasa pertama maupun bahasa asing. Latar belakang pengetahuan sebagaimana dikemukakan oleh Wixon, dkk. di atas erat hubungannya dengan pengetahuan tentang topik dan tentang bahasa (terutama kosa kata) yang digunakan. Whorter menambahkan kondisi fisik dan mental karena dianggap berhubungan dengan kemampuan berkonsentrasi saat membaca, dimana semakin sulit bacaan semakin kuat konsentrasi membaca yang diperlukan untuk bacaan secara detail. Tingkat ketertarikan terhadap topik juga merupakan faktor penting karena dengan rasa tertarik, pembaca akan memiliki motivasi untuk membaca. Selain itu ketrampilan membaca juga merupakan kunci keberhasilan dalam membaca. Ketrampilan yang dimaksud mencakup strategi membaca yang harus diterapkan untuk mencapai tujuan tertentu dalam membaca. Misalnya apabila hanya menginginkan informasi tentang harga sesuatu, pembaca menggunakan scanning strategy dimana perhatian dan mata hanya ditujukan mencari angka dan berhenti saat angka yang berhubungan dengan harga ditemukan.

Ketrampilan membaca pada setiap individu berbeda tergantung dari pengalaman membacanya. Menurut Barr dkk. (2007) kegagalan memahami bacaan dalam bahasa asing disebabkan oleh 3 hal yaitu: 1) strategi pembelajaran membaca di sekolah, pembendaharaan kosa kata yang rendah dan 3) pengetahuan tentang gramatika bahasa yang rendah. Pendapat ini menekankan bahwa belajar Bahasa Inggris sebagai bahasa asing umumnya terjadi di sekolah, sehingga strategi yang dipakai guru sangat menentukan keberhasilan pebelajar dalam memahami isi bacaan. Selain itu unsur bahasa merupakan faktor yang tidak kalah penting. Oleh sebab itu pembelajaran membaca di sekolah harus mempertimbangkan secara hati-hati strategi pembelajaran serta perkembangan bahasa pebelajar. Bahasa harus diperkenalkan secara bertahap dengan tingkat kesulitan yang disesuaikan dengan latar bela- kang kebahasaan pebelajar.

Khusus untuk pebelajar di tingkat universitas, mereka memiliki karakteristik yang khusus yang membedakannya dari siswa sekolah menengah pada umumnya. Dari segi usia, mahasiswa sudah berusia di atas 18 tahun dan terkategorikan sebagai usia dewasa. Menurut Cercone, K. (2008), ada beberapa karakteristik peserta didik usia dewasa. Pertama, pelajar dewasa perlu secara aktif terlibat dalam proses pembelajaran. Kegiatan belajar yang ideal untuk pelajar dewasa harus membuat mereka aktif dan merasa terlibat dalam setiap kegiatan, misalnya dengan menyediakan peluang bagi mereka untuk melakukan penyelidikan, pemecahan masalah, pengembangan diri, dan evaluasi diri. Kedua, pelajar dewasa perlu mengetahui rancangan perkuliahan yang akan diberikan oleh dosen. Jadi sebelum mengajar, dosen harus memberi informasi yang jelas tentang kontrak perkuliahan dimana di dalamnya terdapat tujuan yang akan dicapai, materi yang akan dipelajari, kegiatan di dalam dan di luar kelas yang akan dilalui, dan strategi penilaian yang diterapkan. Ketiga, saat perkuliahan, pelajar dewasa sudah memiliki pengalaman belajar yang panjang dan membutuhkan bentuk arahan atau dukungan untuk bisa meningkatkan pencapaian belajar secara optimal. Keempat, pelajar dewasa atau mahasiswa perlu instruktur atau dosen yang bertindak sebagai fasilitator yang mampu menghubungkan pengetahuan yang dimiliki mahasiswa sebelumnya dengan pengetahuan baru dengan tujuan meng'construct' kompetensi membaca yang maksimal.

Dari penjelasan di atas, bisa disimpulkan bahwa kegiatan pembelajaran untuk pelajar dewasa harus mendorong mereka selalu terlibat, misalnya melalui kegiatan berbagi dalam berdiskusi kelompok atau kelas, posting informasi, melakukan refleksi yang diposting melalui media sosial atau email. Dari pemahaman tentang karakteristik pebelajar usia dewasa, pengembangan materi perkuliahan hendaknya ini pembelajaran harus memungkinkan peserta didik untuk membentuk jiwa kepemimpinan melalui bekerja dalam kelompok. 
Penyusunan materi pembelajaran yang mempertimbangkan tingkat kesulitan sudah lama menjadi perhatian para ahli reading. Ini menjadi dasar berkembangnya teori tentang Level Reading, yaitu teori yang menyatakan tentang perlunya merencanakan bahan bacaan dengan tingkat kesulitan yang direncanakan dengan teliti bagi pembelajaran reading sehingga tingkat kemampuan dan ketrampilan membaca juga tumbuh/berkembang dengan gradasi alamiah (Sarig, 1987).

Menurut Dewan Nasional Guru Bahasa Inggris (National Council of Teacher of English NCTE) (2014), bahan ajar yang relevan adalah bahan ajar yang telah mencapai kesesuaian antara karakteristik peserta didik dengan tingkat kesulitan materi. Kriteria relevan yang dimaksudkan dalam hal ini mengacu pada dua hal yaitu Appropriateness dan Readibility. Appropriateness berarti bahwa bahan bacaan dapat menarik minat peserta didik untuk membaca sesuai dengan keinginannya. Readibility mengacu kepada kriteria bahan bacaan yang dapat mengaktifkan latar belakang pengetahuan peserta didik yang relevan dengan proses membaca lalu menghubungkan pengalaman pribadi mereka dengan pengalaman membacanya.

Kriteria relevansi bahan ajar dalam aspek Reading juga diusulkan oleh Meacham, (2000). Kriteria relevansi ditentukan oleh dua aspek seperti Appropriateness dan Readibility.

Sebuah teks harus berhubungan dengan isi yang dijelaskan dan tujuan dari pembelajaran yang telah direncanakan. Kriteria yang dimaksudkan sebagai bagian dari Appropriateness antara lain:

a. Memiliki analisa yang logis dan berurutan.

b. Mencerminkan perkembangan terbaru dalam penelitian ilmiah.

c. Upaya untuk menafsirkan metode dan hasil penelitian yang berlaku untuk teori dan pernyataan fakta.

d. Memiliki kerangka kerja konseptual yang memberikan arah dan tujuan sementara mencapai ke perspektif teoritis yang konsisten.

e. Memiliki kandungan berdasarkan asumsi diidentifikasi dan dapat diterima dan infor- masi faktual yang relevan untuk setiap konsep diperiksa.

f. Konsisten dalam penggunaan terminologi dan konsep tanpa ambiguitas, hal yang samar-samar, tidak jelas dan makna.

g. Memiliki skema dipertahankan untuk pemilihan material.

h. Upaya untuk fokus dalam mengidentifikasi masalah dan hipotesis yang dapat berfungsi untuk merangsang pemikiran peserta didik dalam penyelidikan.

i. Mendorong peserta didik untuk mempertanyakan berbagai pengamatan dan interpretasi terkait fenomena dilaporkan.

j. Mempromosikan penemuan kreatif dan memberikan 'pertemuan kreatif,' dalam bentuk kasus, dll

k. Penawaran secara bebas terhadap isuisu kontroversial, mengidentifikasi semua sudut pandang, dan jika satu sudut pandang lebih disukai, membuat jelas tentang alasan apa kesimpulan yang ingin dicapai.

1. Memiliki definitif, rinci dan diberi catatan bibliografi, dengan sumber data statistik sepenuhnya diidentifikasi.

Readibility adalah bagian dari kriteria faktor tekstual seperti: bentuk cetakan buku, ilustrasi, jumlah kosa kata, sintaksis, dan pengorganisasian teks.

Dalam penelitian ini, ada empat seri mata kuliah reading yang perlu ditata ulang agar bisa memiliki gradasi, tingkat kesulitan, kedalaman dan keluasan materi yang berkelanjutan. Untuk itu perlu dijelaskan karakteristik dari masing-masing seri sebagaimana yang sintesis dari pendapat Nation (2009) dan teori 'level-reading' (Wagner, dkk., 1997: Sarig, 1987)

\section{Reading 1}

Mata kuliah reading seri pertama ini memiliki level gradasi terendah setingkat pre intermediate dengan karakteristik tertentu. Pertama, dari jumlah panjang bacaan, teks yang digunakan berkisar antara 300-500 kata dengan hanya 5-10\% kata-kata sulit. Materi memiliki media pendukung seperti misalnya gambar, diagram, ilustrasi dan sebagainya. 
Bahasa yang digunakan adalah bahasa seharihari, kalimat pendek, dengan variasi teks yang berbeda-beda.

\section{Reading 2}

Materi pembelajaran pada mata kuliah Reading 2 memiliki panjang yang secara relatif lebih panjang dari teks yang digunakan untuk mata kuliah Reading 1 yaitu dengan panjang bacaan berkisar antara 500-1000 kata. Dari segi tipe/jenis, bacaan bisa berupa teks yang diambil atau modifikasi dari sumber-sumber otentik dengan tema atau topik yang bisa memberi peluang kepada mahasiswa untuk belajar ekstra tentang kosa kata baru, struktur kalimat serta komponen-komponen linguistik lainnya. Materi pembelajaran pada mata kuliah Reading 2 juga perlu dilengkapi dengan ilustrasi seperti diagram, dan gambar berseri untuk membantu mahasiswa memahami dengan cepat. Kata-kata sulit tidak lebih dari 15\% dari jumlah kata keseluruhan dalam bacaan/teks.

\section{Reading 3}

Materi pembelajaran mata kuliah Reading 3 secara relatif lebih panjang dari seri reading 1 dan 2 . Jumlah kata untuk seri ini adalah antara 1000-2000 kata. Teks didukung oleh ilustrasi seperti diagram, gambar, foto, grafik, dan sebagainya. Materi menggunakan kosa kata dengan tingkat kesulitan yang lebih, dengan jumlah kata sulit bisa mencapai $20 \%$. Tingkat kesulitan ditandai oleh kalimat yang kompleks/panjang, klausa dalam jumlah besar pada setiap kalimatnya, singkatan, seringnya kemunculan kualifikasi dan katakata yang tidak biasa digunakan dalam teks. Materi pembelajaran mata kuliah Reading 3 lebih formal dan menggunakan bahasa yang deskriptif, dan variasi lebih besar dalam bentuk kalimatnya

\section{Advanced Reading}

Seri ini merupakan tingkat tertinggi dari Reading berkelanjutan yang ditandai dengan tingkat kesulitan paling tinggi dengan jumlah kata sulit melebihi 20\%. Demikian juga dengan panjang bacaan yang relatif panjang dengan jumlah kata antara 2000-5000 kata.
Materi pembelajaran mata kuliah Advanced Reading memiliki tingkat kesulitan yang lebih tinggi dari level Reading sebelumnya, ditandai dengan kalimat yang panjang, klausa dalam jumlah besar pada setiap kalimatnya, singkatan, seringnya kemunculan kualifikasi dan kata-kata yang tidak biasa digunakan dalam teks.

Karakteristik dari mata kuliah reading berdasarkan level sebagaimana ditampilkan di atas dijadikan salah satu sumber atau pertimbangan penyusunan materi untuk mata kuliah reading berkelanjutan di Jurusan Pendidikan Bahasa Inggris, Undiksha. Dengan demikian mahasiswa calon guru Bahasa Inggris bisa mengalami peningkatan ketrampilan membaca (reading skills) secara gradual.

Selain karakteristik bacaan yang harus sesuai dengan latar belakang pengetahuan dan pengalaman membaca mahasiswa, strategi mengajar dosen juga memiliki peran penting dalam keberhasilan perkuliahan reading berkelanjutan di universitas. Harmer (1998) menyatakan bahwa pengajar yang baik tahu cara mengajar yang baik, tahu apa yang salah dengan pembelajaran yang diampunya dan tahu cara memperbaikinya. Ini menunjukkan bahwa pengajar memiliki pengetahuan dan kecakapan dalam mengimplementasikan suatu strategi pembelajaran yang tepat dalam rangka pencapaian maksimal dari siswanya. Wintergerst, dkk. (2001) mendefinisikan strategi mengajar sebagai langkahlangkah/prosedur nyata yang diambil oleh pengajar untuk mencapai tujuan pembelajaran. Langkah-langkah yang dimaksud misalnya mengelompokkan pebelajar untuk memecahkan masalah, mengerjakan tugas, dan sebagainya.

Ada banyak pengelompokan strategi pembelajaran yang tersedia dalam literatur, tetapi salah satu yang menjadi dasar pengembangan strategi pembelajaran adalah pendapat Killen (1996) yang mengklasifikasikan strategi pembelajaran dasar menjadi 9 yaitu : 1) Pembelajaran Langsung (Direct Instruction/ Teacher-centered) dimana dosen menjadi pusat belajar melalui kegiatan menjelaskan dan mempresentasikan 2) Diskusi (discussion) dimana dosen mengarahkan mahasiswa 
untuk berkelompok dan berdiskusi tentang topik atau isu atau fenomena, dimana terjadi saling memberi pendapat dan pengambilan keputusan bersama 3) Kelompok kecil (small groupwork) yaitu strategi dimana dosen mengelompokkan mahasiswa dalam kelompok 2-3 orang untuk membicarakan atau mengerjakan sebuah tugas yang tidak memerlukan waktu banyak untuk menyelesaikan 4) pemecahan masalah (problem solving) adalah strategi dimana dosen menyediakan sebuah masalah yang harus dicarikan solusinya dalam kelompok maupun individu 5) pembelajaran kooperatif (cooperative learning) yaitu strategi pembelajaran dengan cara mengelompokkan mahasiswa dan saling belajar dan mencapai hasil belajar kelompok dan individu, 6) kegiatan unjuk kerja (performance activity), dimana mahasiswa terlibat dalam kegiatan formal seperti bermain peran, simulasi, berdebat, dan bermain dengan menggunakan Bahasa Inggris, 7) studi kasus (case study) dimana siswa menyajikan situasi yang realistis, kompleks, dan kaya akan situasi secara kontekstual dan sering melibatkan dilema, konflik, atau satu masalah karakter atau lebih dalam kasus yang harus dinegosiasi, 8) menulis (writing) sebagai strategi pengajaran yang difokuskan pada kegiatan mencatat, kegiatan menulis untuk konsolidasi, revisi, dan menulis jurnal; dan 9) pembelajaran inkuiri (inquiry based learning) yaitu strategi yang melibatkan mahasiswa untuk melakukan penyelidikan atau observasi dengan tujuan menjawab pertanyaan yang ditentukan dosen atau pilihan mahasiswa sendiri.

Penelitian tahun pertama ini bertujuan untuk mengembangkan rancangan konten perkuliahan reading berkelanjutan yang dimulai dengan analisis konteks, konten, perangkat, dan proses perkuliahan Reading di Jurusan Pendidikan Bahasa Inggris, Undiksha, melakukan analisis relevansi antara silabus, materi perkuliahan dan strategi perkuliahan yang diterapkan dosen, dan selanjutnya mengembangkan silabus mata kuliah Reading berkelanjutan.

\section{METODE PENELITIAN}

Penelitian ini bisa diklasifikasikan sebagai Penelitian Pengembangan dan Penelitian multi-years. Penelitian Pengembangan (Research and Development) karena memiliki tujuan utama berupa pengembangan silabus dan materi perkuliahan reading berkelanjutan. Penelitian multi-years karena jangka waktu yang diperlukan adalah 3 (tiga) tahun disesuaikan dengan tahapan-tahapan penelitian yang berkesinambungan sehingga hasil penelitian bisa digunakan untuk mengampu mata kuliah reading yang terdiri dari empat mata kilah yang muncul di empat semester secara berturutan.

Pada tahun pertama data dikumpulkan dengan 4 metode: pertama, focus group discussion yang melibatkan 80 mahasiswa (20 mahasiswa untuk masing-masing seri kuliah reading) untuk mendapatkan data tentang materi dan strategi pembelajaran secara umum dan tingkat kesulitan materi; kedua expert judges, yaitu menggunakan tenaga ahli (dosen guru besar di bidang pembelajaran Bahasa Inggris sebagai bahasa asing) untuk menilai relevansi tema dan topik materi dan silabus berdasarkan teori; ketiga, dengan studi dokumen melalui analisis silabus dan materi untuk mendapat gambaran tentang target kompetensi yang ingin dicapai; dan keempat dengan kuesioner untuk mengidentifikasi jenis strategi yang paling sering digunakan dalam pekuliahan.

\section{HASIL DAN PEMBAHASAN}

Pada bagian ini disajikan dan dibahas hasil analisis data yang dikumpulkan melalui keempat metode pengumpulan data yang telah disebutkan sebelumnya.

\section{Pendapat Mahasiswa tentang materi dan strategi perkuliahan Reading}

Analisis terhadap data dari FGD menghasilkan temuan antara lain: 1) Ada ketidak jelasan target pencapaian dari masing-masing seri kuliah reading. Seri yang sama dan diajarkan oleh dosen yang berbeda, tidak memiliki 
kesamaan atau kemiripan materi perkuliahan. Misalnya mata kuliah Reading 1 yang diajarkan oleh dosen A, secara detail mengenalkan jenis-jenis teks (genre-based texts) baik secara eksplisit melalui penjelasan (direct instruction) maupun dengan cara penugasan kelompok dimana mahasiswa menjawab sejumlah pertanyaan dari teks yang dibaca (small group work). Tetapi dosen B menugaskan mahasiswa untuk mengerjakan tugas-tugas dari buku reading yang terdiri dari teks bacaan yang tidak eksplisit mewakili jenis-jenis teks. Pada kelompok ini mahasiswa lebih banyak membaca dan mengerjakan tugas untuk selanjutnya dicek kebenarannya oleh dosen. Dari gambaran ini terlihat bahwa jenis teks yang digunakan serta strategi pengajaran dosen berbeda. Namun demikian menurut mahasiswa, tingkat kesulitan bacaan sudah sesuai $(80 \%)$ dengan tingkatan kemampuan mereka dan tingkatan seri kuliah reading. Dengan kata lain, makin tinggi serinya, semakin sulit teks yang dibaca. Dari strategi pengajaran, dosen banyak menggunakan strategi direct instruction, small group work dan discussion. Tetapi persamaan proses perkuliahan dari keempat seri kuliah Reading adalah tidak ada penjelasan pada pertemuan awal tentang kompetensi yang ingin dicapai pada masing-masing seri mata kuliah.

\section{Relevansi silabus, strategi pembelajaran dan bahan ajar dengan teori ideal pembela- jaran Reading}

Pada tahap awal dilakukan studi dokumen terhadap silabus dengan menggunakan instrumen untuk menganalisis relevansi silabus dengan teori pengembangan silabus oleh Johnson (2006) dan teori karakteristik pelajar dewasa oleh Cercone (2008). Selanjutnya relevansi bahan ajar dengan silabus yang ada dilihat dan teori relevansi bahan ajar oleh Meacham (2000). Data menunjukkan bahwa dari segi silabus, konten silabus ada pada kategori tidak relevan (25\%) jika dibandingkan dengan kriteria silabus menurut Johnson (2006) dimana silabus harus mengandung indikator pencapaian yang terukur, dimengerti, dan dapat dicapai dalam kurun waktu tertentu. Selain itu menurut teori Cercone (2008) pembelajaran harus memiliki target yang jelas dan mahasiswa harus mendapat informasi tentang ini. Pada silabus yang ada juga tidak mencantumkan pengalaman belajar yang jelas dan sumber belajar yang diusulkan kepada mahasiswa untuk memperkaya kompetensi membacanya.

Dilihat dari relevansi bahan ajar dengan karakteristik materi membaca untuk pebelajar dewasa, kesesuaian menunjukkan angka $80 \%$ yang menunjukkan kriteria "sesuai". Materi kuliah Advanced Reading misalnya, sudah memiliki tingkat linguistic complexity yang tinggi dengan penggunaan kata-kata yang memiliki frekuensi penggunaan yang kurang dalam konteks kehidupan sehari-hari. Secara umum relevansi antara silabus, aktivitas (strategi pembelajaran) dan bahan atau materi ajar yang dianalisis dari pendapat ahli (expert judges) dapat dilihat pada diagram batang sebagai berikut.

Gambar 1. Relevansi silabus, aktivitas pembelajaran dan bahan ajar mata kuliah Reading Berseri

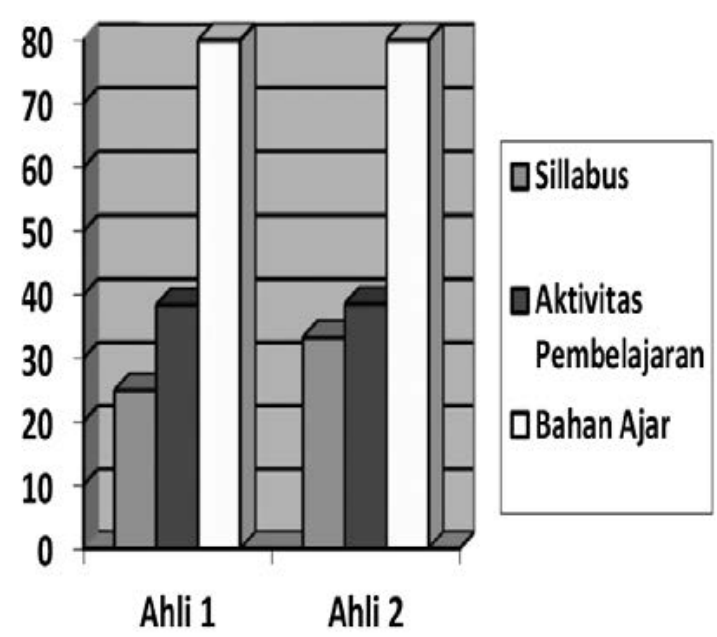

Dari kedua ahli ada konsistensi hasil dimana silabus memiliki relevansi yang lebih rendah dari aktivitas (strategi pembelajaran) dan lebih rendah dari bahan (materi) pembelajaran. Dari segi pengembangan silabus, ada banyak kriteria yang tidak masuk dalam silabus yang ada sebagaimana yang dijelaskan sebelumnya, misalnya rumusan indikator yang tidak jelas dan tidak terukur, pengalaman be- 
lajar yang tidak jelas dan tidak sesuai dengan karakteristik pebelajar dewasa, tidak adanya sumber belajar tambahan bagi mahasiswa untuk belajar mandiri sesuai dengan minat mereka, dan seterusnya. Jika dibandingkan dengan teori Killen (1996) dimana pebelajar dewasa secara ideal perlu memiliki pengalaman belajar melalui 9 jenis variasi strategi, tetapi data menunjukkan adanya penggunaan strategi yang monoton yaitu lebih banyak mendapat penugasan mengerjakan soal melalui kerja kelompok atau diskusi. Ini menyebabkan relevansi strategi pembelajaran hanya mencapai $40 \%$. Namun demikian dari sudut pandang materi ajar, bahan ajar yang tersedia memiliki tingkat relevansi yang tinggi yang ditentukan oleh dua aspek yaitu Appropriateness danReadibility (Meacham, 2000). Ini bisa terjadi mengingat materi reading yang dipakai diambil dari buku-buku reading yang sudah established yang diterbitkan oleh penerbit ternama.

Dari hasil temuan di atas bisa digambarkan bahwa ada masalah dengan rumusan atau konten silabus dari setiap seri mata kuliah Reading di Jurusan Pendidikan Bahasa Inggris, Undiksha, serta ada keterbatasan strategi yang digunakan oleh dosen dalam mengajar sehingga suasana kelas cenderung monoton dan membosankan. Dari temuan ini maka perlu dilakukan pengembangan silabus dan materi perkuliahan yang tidak hanya sesuai dengan silabus tetapi juga memberi peluang untuk penggunaan berbagai strategi melalui variasi tugas (tasks).

\section{Pengembangan silabus mata kuliah Read- ing Berkelanjutan}

Istilah 'berkelanjutan' digunakan dalam penelitian ini untuk menggambarkan adanya kesinambungan antar materi setiap seri mata kuliah Reading. Berkelanjutan didasari oleh jangkauan konsep, tingkat kesulitan linguistik (linguistic complexity), panjang teks dan jenis penugasan. Dari teori yang mendasari penelitian ini, bisa dirangkum karakteristik dari setiap seri mata kuliah reading sehingga terjadi keberlanjutan sebagai berikut.
Tabel 1. Kisi-kisi pengembangan mata kuliah Reading Berkelanjutan.

\begin{tabular}{|c|c|c|c|}
\hline Level & $\begin{array}{l}\text { Konsep, pencapaian } \\
\text { dan jenis penugasan }\end{array}$ & $\begin{array}{l}\text { Tingkat } \\
\text { kesulitan } \\
\text { (Taxonom } \\
\text { y Bloom) }\end{array}$ & $\begin{array}{l}\text { Panjang } \\
\text { (kata) }\end{array}$ \\
\hline $\begin{array}{l}\text { Reading } 1 \\
\text { (Literal } \\
\text { Reading) }\end{array}$ & $\begin{array}{lr}\begin{array}{l}\text { Membuat } \\
\text { antara }\end{array} & \text { koneksi } \\
\text { pengalaman, teks, } & \text { dan } \\
\text { pengetahuan tentang } \\
\text { dunia r pada } \\
\text { umumnya melalui } \\
\text { kegiatan }\end{array}$ & $\mathrm{C} 1234$ & $300-500$ \\
\hline $\begin{array}{l}\text { Reading } 2 \\
\text { (Interpretiv } \\
\text { e Reding) }\end{array}$ & $\begin{array}{lr}\begin{array}{l}\text { Membuat } \\
\text { antara koneksi } \\
\text { teks, }\end{array} \\
\text { pengalaman, dan } \\
\text { pengetahuan tentang } \\
\text { dunia rada } \\
\text { umumnya melalui } \\
\text { kegiatan }\end{array}$ & C2345 & $500-1.000$ \\
\hline $\begin{array}{l}\text { Reading } 3 \\
\text { (Critical } \\
\text { Reading) }\end{array}$ & $\begin{array}{lr}\begin{array}{l}\text { Membuat } \\
\text { antara }\end{array} & \begin{array}{r}\text { koneksi } \\
\text { teks, }\end{array} \\
\text { pengalaman, dan } \\
\text { pengetahuan tentang } \\
\text { dunia } \\
\text { umumnya melalui } \\
\text { kegiatan }\end{array}$ & C3456 & $\begin{array}{l}1.000 \quad- \\
2.000\end{array}$ \\
\hline $\begin{array}{l}\text { Advanced } \\
\text { Reading }\end{array}$ & $\begin{array}{lr}\text { Membuat koneksi } \\
\text { antara } & \text { teks, } \\
\text { pengalaman. dan }\end{array}$ & $\begin{array}{l}\mathrm{C} 456+ \\
\text { extensive } \\
\text { reading }\end{array}$ & $\begin{array}{l}2.000 \\
5.000\end{array}$ \\
\hline $\begin{array}{l}\text { (Reading } \\
\text { from the } \\
\text { media) }\end{array}$ & $\begin{array}{l}\text { pengetahuan tentang } \\
\text { dunia pada } \\
\text { umumnya melalui } \\
\text { kegiatan } \\
\text { menafsirkan, } \\
\text { menganalisis, } \\
\text { mensintesis, } \\
\text { merumuskan, dan } \\
\text { menilai. }\end{array}$ & & \\
\hline
\end{tabular}

Tabel di atas memberi gambaran adanya gradasi materi dari mulai tataran konsep, tingkat kesulitan dan panjang teks. Selanjutnya gradasi ini dicerminkan dalam rumusan kompetensi standar untuk masing-masing seri mata kuliah Reading (Reading 1, Reading 2, Reading 3, dan Advanced Reading) sebagaimana yang dirangkum dalam 4 tabel berikut ini. 
Tabel 2. Penjabaran konsep dan kompetensi standar Reading 1

\section{Nama Mata Kuliah: Reading 1 \\ Jenis text: Genre Text \\ Jumlah SKS: 2 \\ Semester: 2}

Standar Kompetensi:

1) Membaca dan memahami karakteristik berbagai genre teks (naratif, deskriptif, ekspositori, spoof, news item, report, short messages) dari perspektif tujuan/fungsi, struktur bahasa, pemilihan kata dan gaya berbahasa.

2) Membaca dan mengembangkan ketrampilan membaca efektif untuk mengenali suatu genre yang dari genre lain, menjelaskan perbedaan konsep dan struktur kebahasaan.

3) Membaca dan mengembangkan ketrampilan membaca efektif untuk menjelaskan perbedaan, memberi contoh berbagai genis genre teks dengan konteks kehidupan nyata

Pada level Reading 1, mahasiswa lebih banyak berinteraksi dengan teks-teks yang relatif pendek dengan jenis/genre yang ditentukan sehingga selain mengembangkan strategi membaca dan memahami, mereka juga mengenal jenis dan karaketeristik berbagai jenis teks yang bisa ditemukan dalam kehidupan seharihari. Pada level (Reading 2) ada gradasi dari tingkat kesulitan yang dicerminkan dalam kompetensi dasar berikut ini.

Tabel 3. Penjabaran konsep dan kompetensi standar Reading 2

\begin{tabular}{|l|}
\hline Nama Mata Kuliah: Reading 2 \\
Jenis Text: Genre Text dari sumber Otentik \\
Jumlah SKS: 2 \\
Semester: II \\
Standar Kompetensi: \\
1) Membaca dan membangun pengetahuan \\
tentang konsep pengembangan dan penyam- \\
paian informasi dari berbagai genre teks
\end{tabular}

yang terdapat dalam berbagai media otentik

2) Membaca dan memahami konsep generalisasi dan penggunaan linguistic styles untuk mendapat informasi dari berbagai genre teks dari berbagai sumber otentik teks dari berbagai sumber otentik

3) Membaca dan mengembangkan ketrampilan membaca efektif untuk mencari informasi tersurat dan tersirat dari berbagai genre teks bacaan otentik.

4) Membaca dan mengembangkan wawasan tentang konsep, struktur kebahasaan, dan strategi linguistic dari berbagai jenis teks otentik berbasis genre.

Pada level ini mahasiswa berkonsentrasi pada konsep penyampaian dan pengembangan informasi yang ditemukan pada berbagai jenis teks dari sumber otentik. Misalnya dari essay advertorial yang mengkombinasikan deskriptif dengan ekspositori dan sebagainya. Pada seri ini mahasiswa tidak hanya berinteraksi dengan teks untuk membagun pemahaman tetapi juga mengembangkan kemampuan berfikir kritis tentang berbagai strategi penyampaian makna dalam berbagai jenis teks. Selanjutnya, pada seri berikutnya, tingkat kesulitan semakin ditingkatkan sebagaimana yang tersirat pada standar kompetensi berikut ini.

Tabel 4. Penjabaran konsep dan kompetensi standar Reading 3

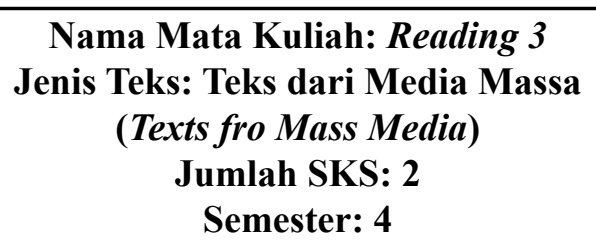

Standar Kompetensi

1) Membaca dan membangun pengetahuan dengan berbagai jenis teks dari berbagai media masa, tujuan/fungsi dan strategi linguistik yang digunakan. 
2) Membaca dan memahami berbagai jenis teks, fungsi, makna dan pesan yang disampaikan melalui berbagai teks dalam berbagai media massa.

3) Membaca dan mengembangkan ketrampilan membaca efektif, memahami makna atau pesan, menggunakan makna dan pesan dalam pengembangan kompetensi berbahasa lisan dan tulis serta mengemukakan pendapat.

4) Membaca dan mengembangkan strategi linguistik untuk menyampaikan pesan melalui tulisan di media massa

Pada tingkatan Reading 3, mahasiswa dikenalkan dengan berbagai jenis teks dari media massa seperti misalnya resume sebuah buku, laporan tentang suatu kondisi politik di sebuah negara, dan sebagainya. Dalam interaksinya dengan teks, siswa berbagai strategi linguistik untuk penyampaian dan pemahaman informasi dari berbagai jenis teks. Pada level berikutnya, pengalaman belajar mahasiswa menjadi semakin kompleks seperti yang ditampilkan pada tabel berikut.

Tabel 5. Penjabaran konsep dan kompetensi standar Advanced Reading

\section{Nama Mata Kuliah: Advanved Reading Jenis Text: Academic dan Non Academic Jumlah SKS: 2 Semester: IV}

Standar Kompetensi

1) Mengembangkan pengalaman membaca dalam genre teks akademik (artikel jurnal, hasil penelitian, opini akademik), memahami gaya linguistik dan penyampaian pesan serta serta struktur kabahasaan teks akademik.

2) Mengembangkan pengalaman membaca dalam genre teks non akademik (essay, artikel populer, karya sastra, memahami gaya linguistik dan penyampaian pesan serta serta struktur kebahasaan teks non akademik.
3) Membaca dan mengembangkan ketrampilan membaca yang efektif untuk teks bacaan akademik dan non akademik, memahami pesan, ide, opini dengan cepat dan mampu memberi tanggapan atau pendapat baik secara lisan maupun tulisan

4) Mampu mengembangkan ketrampilan membaca melalui teks bacaan tambahan (extensive reading) akademik dan non akademik dan mengembangkan ketrampilan menganalisis dan memberi atau mendebat pendapat atau opini dalam teks akademik dan non akademik.

Pada mata kuliah advanced reading, mahasiswa diekspos dengan teks-teks panjang dari genre akademik dan non akademik dengan focus pada kemampuan analitikal, sistesia dan evaluative. Mahasiswa juga ditantang untuk mencari sendiri teks bacaan dengan tema yang sudah ditentukan untuk menambah pengalaman membaca dan mengembangkan ketrampilan membaca secara efektif.

Dari rancangan standar kompetensi di atas bisa dilihat adanya gradasi yang direncanakan berdasarkan teori reading berkelanjutan (levelled reading), karakteristik pebelajar dewasa dan kriteria materi yang ideal. Selanjutnya standar kompetensi tersebut dikembangkan menjadi silabus yang menjadi pedoman dalam penyelenggaraan perkuliahan reading berkelanjutan.

\section{SIMPULAN}

Penelitian ini telah mengidentifikasi permasalahan yang ada dalam perkuliahan reading berkelanjutan di Jurusan pendidikan Bahasa Inggris, Universitas Pendidikan Ganesha. Masalah utama adalah adanya ketidaksesuaian antara silabus yang ada dengan silabus ideal menurut teori Johnson (2006) dan karakteristik pebelajar dewasa oleh Cercone (2008). Namun demikian bahan atau materi pembelajaran reading ditemukan memiliki relevansi yang tinggi dengan teori Meacham (2000) dimana bahan ajar yang dipakai dosen 
memiliki relevansi $80 \%$ dengan teori appropriateness dan readability yang disarankan. Hal ini wajar mengingat buku-buku yang dipakai diterbitkan oleh penerbit yang bereputasi internasional. Jadi penelitian ini sangat perlu untuk dilanjutkan dengan perancangan dan pengembangan silabus yang sesuai dengan teori reading berkelanjutan, karakteristik mahasiswa dewasa dan standar ideal sebuah silabus. Dengan demikian kualitas pencapaian pembelajaran reading bisa ditingkatkan karena adanya target yang jelas dan materi yang berjenjang dan sistematis.

\section{DAFTAR PUSTAKA}

Amri, S. 2010. Konstruksi pengembangan pembelajaran. Jakarta: Prestasi Pustaka.

Artini, L P, Ni Nyoman Padmadewi, Putu Kerti Nitiasih. 2014. Pengembangan Model Perkuliahan Reading Berkelanjutan Ber basis Kurikulum 2013 Jurusan Pendidikan Bahasa Inggris Fakultas Bahasa Dan Seni Undiksha. Universitas Pendidikan Ganesha, Singaraja.

American Council on The Teaching Of Foreign Languages (ACTFL). 2012. English Pro ficiency Guidelines. Retrieved, June 15 2015 from http: //www.actfl.org/ publications/guidelines-and-manualsactfl-proficiency-guidelines-2012

Brown, H.D. 2000. Principles of Language Learning and Teaching. San Francisco: Addison Wesley.

Bailey, K.M. 2005. Practical English Language Teaching Speaking. Singapore : McGrawHill

California Sate Broad of Education. 2002. English-Language Development Standards for California Public Schools. Sacramento: California Department of Education.

Claire J. 2006. Best Practices in Syllabus Writing: Contents of a Learner-Centered Syllabus. Journal of Chiropractic Education Volume 20, Number 2. Southern California University of Health Sciences

Crain W. 2007. Teori Perkembangan Konsep Dasar Dan Aplikasi. Pustaka Pelajar.

Cercone. K,. 2008. Characteristics of Adult Learners with Implications for Online Learning Design: Association for the Advancement of Computing In Education
Journal. Volume 16, Number 2. State of Connecticut Milford, CT USA

Cahyono, B. 2009. The teaching of EFL reading in the indonesian context:The state of the art. TEFLIN Journal, Volume 17, Number1.Universitas Negeri Malang, Malang.

CAST. 2011. Universal design for learning guidelines version 2.0. Wakefield, MA: Author.

Depdiknas. 2002. Kurikulum Berbasis Kompetensi (Competency-BasedCurriculum). Jakarta: Pusat Kurikulum, Balitbang Depdiknas.

Cologon, K., \& McNaught, M. 2013. Early intervention for literacy learning. In L. Arthur, J. Ashton, \& B. Beecher (Eds.) Diverse literacies and social justice: Implications for practice. Melbourne: 